\title{
Leadership Influence on Quality Enhancement of Community Colleges
}

\author{
Babu Ram Bhusal, M. Phil \\ Lecturer \\ Department of English \\ Janamaitri Multiple Campus, Kuleshwar, Kathmandu, Nepal \\ Email: brbhusal@hotmail.com
}

Peer Reviewed by : Prof. Dr. Anjana Bhattarai

Prof. Dr. Bal Mukunda Bhandari

\begin{abstract}
This study was conducted as an attempt to see the influence of educational leadership on employees for motivating them in quality enhancement mission. The assumption behind it was the need of creative and innovative leadership for motivated and efficient team spirit in quality education. The research questions were centralized in the leadership perceptions and their strategic efforts for imparting quality education. The philosophical and theoretical support of transformational leadership theory and continuous improvement approach strengthened the research. The researcher adopted interpretive research paradigm with in-depth interview and field observation as primary sources and various printed documents as the secondary sources. The basic data were generated from twelve participants of three different community colleges. The perceived data were presented and interpreted under various themes via perceptions and efforts in quality enhancement, leadership influence on employees, human resource development and mobilization for institutional strength and shifting threats into opportunities. The findings hint varied and insufficient attempts of leaders for addressing growing needs of these colleges. The concluding remarks further encourage college leaders in general and community college leaders in particular to plan and implement farsighted strategies to cope with the ever widening challenges in academia.
\end{abstract}

Keywords: Academia, leadership influence, team-spirit, professionalism, transformation, strategies, employee satisfaction. 


\section{Background of the Study}

Originally developed to be an extension of high school, community colleges have become an essential part of the nation's educational fabric (Cunningham, 2009: 60). The statement illustrates the scenario of community colleges in USA where community colleges were established to meet the requirements of the people of lower strata. In Nepalese context the political change of 1990 A.D. begot a large number of community colleges to serve the educational needs of common people (B. N. Ojha, President of Public Campus Association, in personal communication February 25, 2018). Since then, the community colleges are found devoted in the service of the nation.

The leaders of community based colleges feel themselves responsible to envision strategies and set framework for the effective implementation or procurement plan in long and/or short term basis (Astin and Astin, 2000 as cited in Schmitz, 2008: 9). Leadership is inherently value-based and concerned with fostering change. They try their best to exhibit task oriented and relation oriented behavior in such a way that they maintain closer proximity with the fellow employees. Such kind of behavior obviously leads to the feeling of change oriented behavior and realization of organizational citizenship. The rational mind set of these leaders and their field performances have to go in the same line for the inspirational motivation of the esteemed members.

Dahlgaard, Kristensen \& Kenji (2007) gave visionary expressions that "leadership is the driving force behind policy and strategy, people management, resources and processes leading ultimately to excellence in result" (p.212). Leaders of academic institutions need ideal personality, inspirational role model, visionary ideas, long term development strategies and transparent management skills to address the expectations of the stakeholders. Their administrative and managerial skills ensure institutional sustainability and time specific transformation of the institutions amid the competitive educational market as 'doing things properly' for competitiveness and profitability (Dahlgaard, Kristensen \& Kenji, 2007: 14).

Quality education tends to enable the learners with their ability to generate skills, gain sustainability, adopt professionally and demonstrate change (Tomlinson, 2004). In fact, quality has to be defined from the angle of adjustment of the learners after the completion of academic programs. The above stated definition of quality education hinted that life skills, changes in living standard, confidence in person, role awareness and the like can be additional indicators while explaining quality of education. The prominent steps in a quality program are management commitment and a quality improvement team (Sallis, 2002: 45). If the leaders fail to address the expectations and to regard the potentiality of the fellow warriors in time, their capacity will be either unproductive or counterproductive in long run. 
While thinking about quality education in our context, the contribution of community colleges deserves importance. The community colleges were in a unique position to attend the needs of many underserved populations (Cunningham, 2009: 14). We find involvement of local community in the establishment and operation of community colleges and the property ownership remains within the institution and ultimately to the nation. In reality, community colleges have been offering their services to the nation generating the resources on their own and not for profit motive. The existing chaotic socio-political condition and strong grips of technology have positively challenged the leadership of these colleges to formulate and implement certain time specific strategies to combat the upcoming threats. A successful leadership with strong vision, missions, goals and objectives is strongly mandatory in this grand work. The role of present leaders, involved in these colleges, determine the destiny of the entire institution and help in paving the future road map of the nation's education.

Amid above mentioned conditions and rapidly advancing technological practices, the leaders of higher educational institutions are passing very hard time in their jobs. The fellow employees are to be motivated in such a way that their collective efforts pave the future road map of higher education towards time specific and demand driven outcomes. The leadership, in this sense, has to play the role of catalyst to foster competitive advantages. If the leaders create values, nurture employees, give them responsibilities and make them accountable in their esteemed profession, their employment turns into ownership. This situation ultimately leads to institutional success. This research makes its bases on the same issue with the need of sustainability and struggle for valuable existence.

\section{Statement of the Problem}

Schmitz (2008), in his doctoral thesis, expressed his opinion that "community colleges are known for their ease of access, excellent academic programs to meet learners' needs, low cost and a broad array workforce training" (p.1). Community colleges were intended to educate the underserved including women, minorities, and working adults (Cunningham, 2009: 14). The community colleges get affiliation from the universities and left in the form of autonomy without any specific guidelines. As a result, the educational leaders of these community colleges are compelled to struggle for academic excellence provided with very nominal resources. Globalization, increased competition, teachers' professionalism, and technological changes, as well as teacher and student diversity, make the requirements of leadership increasingly complex (Dhakal, 2013: 2). Advancement in the field of science and technology, globalized educational market, turbulent socio-political situation, and growing need of competing with private sector are some of the numeral challenges that the community colleges are compelled to face. The leadership of community colleges, therefore, is working at the razor's edge and their existence depends entirely on the education they impart. 
How do the leaders of community colleges perceive the concept of quality education? How do they make visionary strategies in the line of quality enhancement? How do they get success to motivate all the stakeholders in the overall development of college? How do they tackle the unfavorable situations in course of leading? How do they get support from the fellow members? Such crucial concerns gave ground to this research.

\section{Purpose of the Study}

The main purpose of this research was to study and explore the influence of leadership in motivating the employees for improved performance. More specifically, the study attempted to analyze and describe the perception of college leaders and fellow employees about quality education and their inspirational strategies to promote integrated teamwork for continuous improvement in quality.

\section{Research Questions}

The following research questions, as the guiding principles, had been set so as to achieve the purpose of this research:

- How do the community college leaders perceive the concept of quality education?

- What strategic activities help them promote integrated teamwork for continuous improvement in quality?

- What problems and opportunities do they find in their leadership practices?

\section{Review of literature}

Blaxter, Hughes \& Tight, (2006) express their views that, "a literature review is a critical summary and assessment of the range of existing materials" (p. 122). The literature of this research has been placed under the following headings:

\section{Transformational Leadership for Innovation in Academia}

The concept of transformational leadership was coined by James Mac Gregor Burns (1978) in his famous book on political leadership and enlarged by Bernard M. Bass (1985). It is a highly advocated and trusted model for academia in which the leaders reach beyond the effects of established norms by transforming the followers towards changed visionary organizational structure. "Transformational leaders transform the personal values of followers to support the vision and goals of the organization by fostering an environment where relationships can be formed and by establishing a climate of trust in which visions can be shared" (Bass, 1985 as cited in Stone, Russell and Patterson, 2004). This definition focuses on the formation of long term organizational vision and mission to impress/inspire the followers for their self-devotion in the organizational mission.

Transformational leadership is the process whereby a person engages with others and creates a connection that raises the level of motivation and morality in both the leader 
and the follower (Northouse, 2008: 176). The value driven leadership succeeds in motivating the followers to abandon their personal and devote for the sake of radical change in organization. Similarly, Luthans (2008) says that "transformational leadership is based more on leaders' shifting the values, beliefs, and needs of their followers" (P.424). Transformational leaders provide vision and sense of mission for the overall development of organization and all round development of its members. This sort of innovative environment promotes intelligence, rationality, creativity and sense of transformation in organization.

Stone, Russell \& Patterson (2005) are of the opinion that transformational leaders solicit their followers' ideas and creative solutions to problems (p.351). Being dynamic in nature, transformational leadership can be regarded as an ideal leadership for all ages because it encourages the procedures of searching advanced options to substitute outdated ones. Transformational leadership theory advocates the ideal mechanism of leadership in which the followers are gradually empowered for responsibilities so as to free the leaders from their day to day responsibility. The leaders at the same time can be involved in further innovative works. Shared vision, maximum upliftment of individual knowledge, promotion of team spirit, opportunities for leadership development, high level motivation etc. are some of the numeral strategies of transformational leadership that distinguish it from other general leadership models.

According to Bass (1990) transformational leaders embody the four traits or characteristics via idealized influence, inspirational motivation, intellectual stumulation and individualized consideration. The leaders having these characteristics demonstrate balance between institutional progress and employee development.

\section{Continuous Improvement Approach}

Continuous Improvement (CI) Approach, as defined by Temponi (2005), is developed from Japanese word kaizen, which means incremental improvements of the on-going processes. It is a realistic, proactive and measurable approach to quality (p.3). He further opines that the process of continuous improvement includes people, equipment, supplies, materials, and producers. He has quoted CI cycle of Deming and Shewart known as the P-D-C-A (i.e. plan, do, check and act) in the line of demonstrating how the process of implementing CI approach can advance. The seventh and thirteenth of Deming's fourteen points via institute leadership and institute a vigorous program of education and self-improvement respectively worth value in the context of continuous improvement as an approach.

Deming's 5th Principle of Transformation aims to improve constantly and forever the system of production and service, to improve quality and productivity, thus constantly decrease costs (Deming, 1986, as cited in Redmond, Curtis, Noone and Keenan 2008). This principal best matches the basic attempts of transformational leadership 
and seems applicable in higher educational institutions in the sense of striving to be responsive to the needs of students and other stakeholders, improving and developing curricula, promoting the highest standards of scholarship in teaching and research and in constantly questioning if courses are achieving their intended outcomes (Redmond, Curtis, Noone and Keenan, 2008: 436). The above mentioned theories indicate that the academic leaders need to perform their visionary leadership in the line of job satisfaction, organizational commitment, efficient teamwork and quality enhancement for the sustainability of these community colleges.

\section{Policies and Practices for Quality Enhancement}

In the international scenario demand driven education is prioritized with the slogan 'education for life'. According to The Dakar Framework for Action (2000), the education system of USA recognizes the social and professional value of teachers as essential actors within quality education by establishing agreed-upon policies for certification, improvement of working conditions, remuneration and incentives for continuing improvement of professional skills (p.35-42). Along with the slogan of inclusive education they opened the academic avenue for the joint efforts of the state and community for quality education.

Chapman \& Adams (2002), in a study of education of Developing Asia, found inadequate teacher in-service trainings, low salaries and misallocation of teachers as major problems and constraints in higher education quality in Philippines (p.13). The problems facing education systems in South and Southeast Asian countries often appear to be alike, for example, poorly trained teachers, inadequate supply of textbooks, weak management, little or no instructional supervision and poor facilities (Chapman and Adams, 2002: 68).

In Nepalese context the Tenth Plan (2002) urged universities to "develop qualitative, participatory and competitive higher education in different disciplines" (p.456). The policies opened higher avenues for the expansion of higher education in full fledge. The practices, however, were with higher difficulties and opportunities along with several vicissitudes. Both internal political instability and rapid globalization seem equally responsible behind present chaotic situation in academia. Neither the quality of education sector is in the nation's grip nor do the policy makers seem successful to formulate long term education policy that ensures bright picture onwards. As a result, the need of a visionary national education policy with due clarity regarding quality, equity and access was realized. Vanlalhriata's research on leadership influence (2009), Pokharel's study on head teacher's leadership style (2011) and Khadka's study on job satisfaction of institutional school teachers (2010) stand in the line of this research with the need of dedicated human capital in the path of academic excellence. 
The process of quality enhancement is highly diversified and its accountability is further complex in real practice because there is no any specific pin pointing framework to measure them in terms of quality. Though we find a large pool of researches in the field of leadership efforts and quality performance, there is serious lack of this study in community colleges of our context. To cope with the growing challenges in academia, community college leaders are supposed to be more strategic. This research was expected to unravel the perceptions and practices of this field prevailing in community colleges so as to fulfill the existing gap.

\section{Research Methodology}

Research is the process of making claims (Creswell, 2003: 7) and research method is a road map to carry on the activities of research in smooth way without any kind of bewilderments. It advocates or develops logic behind particular method used by the researchers in the context of their study and explains why the researcher is using a particular method or technique (Kothari, 2002). This research was guided by the norms that qualitative approaches allow room to be innovative and to work more within researcher-designed frameworks (Creswell, 2003: 23).

This research was conducted adopting interpretive research paradigm to see the existing leadership practices in community colleges of Nepal with the impact on quality enhancement. Interpretation was taken in the form of analysis with support from the side of established knowledge. As materials for discussion, both the primary and secondary sources of data were interpreted under various themes giving specific shape to the findings. The theoretical bases of this research were Transformational Leadership Theory (Burns, 1978; Bass, 1985) and Continuous Improvement Approach (Temponi, 2005).

The data were generated from both primary sources comprised of the information collected from the lived experiences of the participants and various printed materials as the secondary sources. The respondents of primary sources were the campus chiefs, program coordinators and senior faculties whereas secondary data were collected from various printed documents including books, research journals, research reports, policy documents etc. including the UGC publications. Similarly available policy plans, bulletins, magazines, internal rules and regulations, and periodical minutes of study location also were highly supportive to strengthen the information of this research. In-depth interview, field observation and field notes were used as the tools of data generation.

Richards (2003), states that analysis is neither a distinct stage nor a discrete process; it is happening within interpretation. In other words the process of interpretation proceeds side by side along with the analysis without any specific demarcation between these two. Likewise, Patton (2002) is of the opinion that interpretation involves explaining the 
findings, answering why questions, and attaching patterns into an analytical framework. The present research generated the central themes in inductive way. "Inductive analysis means that the patterns, themes and categories of analysis come from the data; they emerge out of the data rather than being imposed on them prior to data collection and analysis" (Patton, 1980, as cited in Bowen, 2005: 217).

The analysis firstly focused on declaring the central issues or themes of data based on the research questions. Then the content was described and analyzed identifying, coding and categorizing the primary pattern of data. The three co-moving steps known as data reduction, data display and drawing conclusion and verification were applied and the contents were coded and categorized according to the research questions. The main guidance to the findings was given and conditioned by the theories and approaches discussed above. Those guidelines along with the research questions brought the interpretations in the right track. The researcher's minute observation of the site, records of the stakeholder remarks, study of the available printed materials etc. were given due emphasis in course of meaning formation.

\section{Discussion of the Findings}

The entire process was guided by the understanding that the analysis of qualitative data is an ongoing process involving continual reflection about the data, asking analytical questions and writing memos throughout the study (Creswell, 2003), summarizing, condensing, and illustrating what the researcher identifies as the main themes (Smith, Flowers and Larkin, 2009). The findings of this research have been discussed under the following sub-headings:

\section{Perspectives on Quality Education}

The participants were found having sound understandings about the norms of quality education. Out of the established debate of input, process and output, as an achievement of educational institutions, all the participants emphasized on the priority to consequences or achievement as an outcome. The administrators remarked in the interviews that the educational institutions should impart the kinds of academic qualities and working skills to the learners that they adjust in their working fields without difficulties and such kind of efforts can be made by creative and dedicated teachers. The expressions reminded the ideas of Dahlgaard, Kristensen and Kenji (2007) who projected quality issue as a holistic concept that included two different ideas i.e. quality as 'consistency' and quality as 'fitness for purpose' (p.14). In fact, their realizations were related to the theoretical ground that quality service tends to enable the learners with their ability to generate skills, gain sustainability, adopt professionally and demonstrate change (Tomlinson, 2004).

The perceptions of the research participants reflected their maturity in understanding towards the concept of quality education. Though the expressions differed in person, 
the central emphases of almost all the participants were found with similar opinion and none of them gave priority to the grades or percentage of the certificates only. In other words, the respondents were found well aware and motivated towards the modernized concept of demand driven education which fits the concept of quality in term of 'fit for purpose' (Sallis, 2002: 13).

\section{Quality Enhancement Efforts}

Regarding the efforts for quality enhancement Martin and Marion (2005) remark that "the leader must cast a critical eye on existing policy and programs to seek new and better methods to achieve organizational objectives" ( p.149). The leaders, in the same regard, are the change agents or torch bearers of the team who play front and prominent role on how to transform life through education. The discussions were based on the norms of continuous improvement approach that systems and procedures need to be improved, reorganized or re-specified to improve academic quality. The common causes of quality failure can include poor curriculum design, unsuitable and poorly maintained buildings, poor working environment, unsuitable systems and procedures, insufficiently creative timetabling, a lack of necessary resources, and insufficient staff development (Sallis, 2002: 38).

The respondents representing the administrative role claimed balanced mobilization of staff and combined effort as the supporting measures of quality enhancement. The faculties, on the other hand, charge the administration for failing to adopt modern teaching learning strategies, inadequate resource mobilization for practice based teaching and unwillingness to adopt change. During the field observation it was realized that the college had to seek some alternative ways of students' skill development in place of traditionally practiced teaching learning activities. The traditional approach was found against the version of Sallis (2002) that "the majority of quality problems are the fault of poor management, rather than poor craftsmanship" (p. 43). The leaders had to impose their visionary ideas as idealized influence i.e. providing vision and sense of mission, instilling pride, and gaining respect and trust (Robbins, DeCenzo, Bhattacharya and Agarwal, 2009: 457).

\section{Human Resource Development}

The research took continuous learning as the base of quality and the worth of the people as the keys to quality (Dahlgaard, Kristensen and Kenji (2007: 212). Learning organizations (Senge, 1990) demand people continually expanding their capacity to create the result they truly desire, where new and expensive patterns of thinking are nurtured, where collective aspiration is set free and where people are continually learning to learn together. The respondents of this research stood in the same line that organizational scheme to staff development through facilitating team learning for adaptation to change, quality of performance strategies and collective efficacy (Yukl, 2008: 343). The respondents with administrative responsibilities were of the opinion 
that staff development strategies were adopted by the campuses and University Grants Commission had provided continuous support in this scheme. The teaching faculties, however, were not found fully satisfied with the progress of the colleges in course of meeting the growing needs and demanded better leadership efforts ahead.

In an educational setting transformational culture is a function of staff motivation and efficient leadership in a setting that is student centered (Sallis, 2002: 15). Only the satisfied and motivated staff in combined form can dedicate their efforts for the good of the students. While asking the situation of staff satisfaction and motivation in real practice, the respondents from the administrative side remarked that the colleges have kept the provision of time specific permanency, provident funds, retirement benefits, leave payment and financial support to $\mathrm{M}$. Phil / Ph. D. studies for motivating the staff. The above stated words supported the version of Sallis (2002) that employee motivation and the importance of pride, joy and job satisfaction play key roles in the delivery of quality services" (p.41). Well motivated staff, in this sense, would deserve power to succeed.

The teaching faculties, however, objected on the above remarks that the colleges had given permanent appointment to around one third staff only and most of the above stated provisions were applicable to the permanent staff only. The motivating strategies applied to the one third staff go against the views of Schmitz (2008) who opined that effective transformation required creative involvement of everyone throughout the organization (p.12). The colleges need to adopt the provision of staff development in uniformed way to formulate effective team spirit.

\section{Converting Threats into Opportunities}

The respondents of all the categories expressed their varied opinion that they had to dedicate their efforts in the organizational mission of quality education for quality life. They expressed their views that they could convert their threats into opportunities in near future if the leaders got success to demonstrate ideal leadership. Their hopeful expressions reminded Avolio \& Bass (2002) that the leader's influence helps others to look at the futuristic state, while inspiring acceptance through the alignment of personal values and interests to the collective interests of the group interests (As cited in Stone, Russell \& Patterson, 2004: 350). The discussions commonly reflected perceived philosophy that the leaders were created to convert threats into opportunities. The respondents from the side of general administration were of the opinion that the leadership could do more than the prevailing situation. Regarding the threats, they showed the problems related to program expansion, alternative to plus two phasing out, library, lab, and technology based teaching. In this sense, of two levels of threats were understood prevalent in front of her college via internal and external threats. 


\section{Conclusion}

The findings suggested that the educational leaders of present times need to impart such kind of education that ensures professional settlement of the learners as an outcome of their studies. It inspired us not to limit the scope of education to the mere degrees or merits that the learners get at the end of the academic sessions via summative evaluation. Such understanding is slightly in the same line with Dahlgaard, Kristensen and Kenji (2007) that quality service has to ensure customer satisfaction, people satisfaction and impact on society. The research intended to seek the need of some specific strategies to modify the services of academic leaders in demand driven way.

Though the leaders were found having desire of imparting best quality education, the efforts were not uniformly applied. The strategies such as subject-wise project works, learner centered and research based teaching, students' presentation, field visits, collaboration with different organizations, additional assignments for preparatory exercises, opinion sharing expressions, role play etc. were found insufficient in the field. For the sustainable development, the leaders need to formulate and implement some sort of visionary strategies as the road map to face ever increasing challenges and to grab widely emerging market opportunities.

Similarly the research findings show that quality depends on the development and motivation of the employees to a greater extent. The colleges can develop a unit to conduct trainings, seminars, workshops, field trips and many such schemes so as to enable the staff cope with the growing market demands. Likewise the colleges need to make the employees realize themselves to be the most responsible and authorized members of the institution. Some of the motivating factors include incentives, permanency, promotion, security, retirement benefits, self-esteem, and impartial performance appraisal. The findings resembled the application of Maslow's Hierarchy of Needs Theory (Robbins, DeCenzo, Bhattacharya and Agarwal, 2009: 194) that covers five basic needs of human beings on priority basis via physiological, safety, social, esteem and self-actualization. It hinted the situation that community colleges need to gear up in their strategies to face the growing competitions with government supported constituent colleges and mushrooming private colleges with massive investments. All these colleges need to convert the perceived threats into opportunities. The ultimate way to reach such a destination is visionary leadership with strong commitment and bold support of an efficient and satisfied team spirit.

\section{References}

Bass, B. M. \& Riggio, R. E. (2006). Transformational leadership. New Jersey: Lawrence Erlbaum Associates.

Blaxter, L., Hughes, C. \& Tight, M. (2006). How to research (3rd ed.). New York: Open University Press. Bowen, G. A. (2005). Preparing a qualitative research based dissertation: Lessons learned. In the Qualitative Report 10 (2). Retrieved from http:/www. Nova.edu/ssss/QR/QR10-2/bowen.pdf. 
Chapman, D. \& Adams, D. (2002). The quality of education: Dimensions and strategies. In Education in Developing Asia Vol.5: Asian Development Bank.

Creswell, J. W. (2003). Research design: Qualitative, quantitative and mixed methods approaches (2nd ed.). New Delhi: SAGE Publications.

Cunningham, D. H. (2009). "Baby Boomers and Community College: A Study of Motivations". Unpublished Dissertation of Doctor of Education: Oklahoma State University, USA.

Dahlgaard, J. J., Kristensen, K \& Kenji, G. K. (2007). Fundamentals of total quality management. New York: Taylor and Francis.

Dhakal, R. K. (2013). "Leading at the Edge of Chaos: Perceptions and practices of Nepalese school leaders". An Unpublished Dissertation of M. Phil, Kathmandu University, Nepal.

Khadka, J. (2010). "Job satisfaction of institutional school teachers of Kathmandu District of Nepal". Unpublished M. Phil Dissertation, Submitted to Kathmandu University, Nepal.

Kothari, C. R. (2002). Research Methodology: Methods \& Techniques (2nd ed.). New Delhi: Wishwa Prakashan.

Luthans, F. (2008). Organizational behavior (11thed.). New York: McGraw Hill.

Martin, J. S. \& Marion, R. (2005). Higher education leadership roles in knowledge processing. In the Learning Organization. 12 (2). Emerald.

Northouse, P. G. (2008). Leadership: Theory \& practice (4th ed.). Delhi: Sage Publication.

Patton, M. Q. (2002). Qualitative research and evaluation methods (3rd. ed.). New Delhi: Sage Publication.

Pokharel, I. P. (2011). "The effect of head teacher's leadership styles on teacher motivation: A study of government schools of Lalitpur district". Unpublished M. Phil dissertation submitted to Kathmandu University, Nepal.

Redmond, R., Curtis, E., Noone, T., \& Keenan, P (2008). Quality in higher education: the contribution of Edward Deming's principles", International Journal of Educational Management. 22(5) pp.432441. Available at http://dx.doi.org/10.1108/095135408 10883168

Richards, K. (2003). Qualitative inquiry in TESOL. Hampshire: Palgrave Mac Milan.

Robbins, S. P., De Cenzo, D. A., Bhattacharya, S. \& Agarwal, M. N. (2009). Fundamentals of management: Essential concepts and applications. New Delhi: PEARSON.

Sallis, E. (2002). Total quality management in education. London: Stylus Publishing Inc.

Schmitz, G. R. (2008). "Leadership preparation and career pathways of community college presidents". Unpublished Doctoral Dissertation, Iowa state University, USA.

Senge, P. M. (1990). The fifth discipline: the art and practice of learning organization. New York: Double Day.

Smith, J. A., Flowers, P., \& Larkin, M. (2009). Interpretive phenomenological analysis: Theory, method and research. Thousand Oaks, CA: SAGE Publications Inc.

Stone, A. G., Russell, R. F. and Patterson, K. (2004). 'Transformational vs. servant leadership: a difference in leadership focus.' In The Leadership \& Organization Development Journal, 25(4), 350. DOI 10. $1108 / 01437730410538671$.

Temponi, C. (2005). Continuous improvement framework: implication for academia. Quality Assurance in Education. 13(1). pp.17-36. Retrieved from www.emeraldinsight.com/ 0968-4883.htm.

Tomlinson, H. (2004). Educational Leadership. London: SAGE Publications Ltd.

UGC Nepal, Annual Report, 2010. University Grants Commission, Sanothimi, Bhaktapur, Nepal. Website: www.ugcnepal.edu.np.

UGC Nepal, Education Management Information System: Report on Higher Education (2010).

UGC Nepal, Education Management Information System: Report on Higher Education (2011/12).

Vanlalhriata, J. M. (2009). "Influence of leadership style of principals on school climate and commitment of teachers." Unpublished M. Phil dissertation submitted to Kathmandu University, Nepal.

Yukl, G. (2008). Leadership in Organizations. New York: Pearson Education. 